\title{
Affordable Housing Ambidexterity of Real Estate Investment Trusts: SWOT Analysis for N-REITs
}

\author{
Oluchi Adeline Diala ${ }^{1} \quad$ Nonso Izuchukwu Ewurum ${ }^{2} \quad$ Chicheta Francis Nissi $^{1}$ \\ 1.Estate Management, University of Uyo, Akwa Ibom, Nigeria \\ 2.Estate Management, University of Nigeria Nsukka, Enugu, Nigeria
}

\begin{abstract}
Symmetric movements of real estate investment trust (REIT) capitalization and affordable housing deficit in Nigeria fuelled the motivation of the study on analyzing the implications of an affordable housing ambidexterity of REITs in Nigeria (N-REITs). The focus on REITs was informed by the unsustainable growth in the deficit statistics of affordable housing in Nigeria which implies a think-outside-the-box search for financing panacea. Indeed, there seems a paucity of empirical and practical evidence of such ambidextrous diversification for $\mathrm{N}$ REITs, so the study was aimed at conducting a strength, weakness, opportunity and threat (SWOT) analysis of affordable housing ambidexterity of N-REITs. Survey research method was employed on a sample frame of housing delivery stakeholders. Sample size of 369 was determined using Freund and Williams formula, while the research instrument was a self-administered e-questionnaire. Data was obtained from primary sources, and further subjected to descriptive analysis. The study found that professional investment management competency was the most dominant strength, $10 \%$ investable income was the most significant weakness, significant room for rise in market share was the most significant opportunity, while effect of systematic risk on sustainability planning was the most significant threat to N-REIT ambidexterity towards affordable housing investment in Nigeria. The study concluded that the professional investment management quality of REITs, in comparison with non-listed direct real estate companies would envisage a robust and sustainable contribution to increase in affordable housing stock in the country. It was recommended that management of N-REITs should leverage on their professional investment management strengths to explore blue ocean strategies for an ambidextrous attitude that enhances the growth and sustainability of affordable housing units, in addition to the employment of risk analysis, management and mitigation strategies to limit the effect of volatilities from macroeconomic risks.
\end{abstract}

Keywords: Housing affordability, Housing deficit, Housing financing, REITs, REIT ambidexterity, SWOT analysis.

DOI: $10.7176 / \mathrm{EJBM} / 13-12-02$

Publication date:June $30^{\text {th }} 2021$

\section{Introduction}

The urban housing deficit surge in Sub-Saharan Africa remains uncontrolled in recent years with over 56 million-shortfall, out of which Nigeria alone has over 17 million. Of the 56 million, Yinglun (2019) assert that an estimated 45 million units, representing $90 \%$, is in the affordable housing bracket. This is corroborated by 2015 and 2020 reports from World Bank housing delivery analysis in the region which present grim statistics that over 40,000 persons migrate from rural to urban areas daily in the continent, culminating in over 4.5 million new informal residents annually. Onyekwelu et al. (2020) lend credence to this assertion with the argument that "rental affordability issues have forced a significant proportion of urban settlers in lower middle-income countries into contiguous settlements". These anomalies have been juxtaposed with a myriad of housing policy and finance challenges across the continent.

For instance, the 2015, 2020 World Bank reports levy a significant dose of culpability on policy issues as ineffective physical planning, basic infrastructure deficit, inflation management inefficiency, cumbersome regulatory requirements (with an "average of 162.2 days to obtain a construction permit"), and proliferation of informal settlements. From the financial perspective, issues as limited number of developers with requisite technical and financial strength for large-scale residential real estate investments amidst underdeveloped financial systems with about 5\% mortgage loan viability. Some quarters have actually disputed this $5 \%$ as generous with the argument that a more realistic statistic suggests that "a trifling 3\% of Africans can afford a mortgage" (Kieti \& K'Akumu, 2018). When such housing finance impediments are juxtaposed with mean property and title registration costs which stand at over $8 \%$ of property value (World Bank, 2015), it can be easily agreed that some form of housing investment dilation is required.

The housing sector plays vital roles in economic growth and diversification sustainability. For this to be attained, a fair degree of criticality must be attached to the proportional contribution of the housing industry to the gross domestic product (GDP). In perspective, amelioration of capitalization opportunities for affordable housing delivery has directly significant positive externalities to economic development through enhanced occupant affordability with prospects of increased savings and investment potentials, increased opportunities for employment generation. Such capitalization, with its attendant benefits for Sub-Saharan Africa, is also 
unfortunately beyond their capacity (Aliu et al., 2018; Gillespie, 2018; Suhaida et al., 2011). Real estate investment trusts (REITs) epitomise one policy and economic option for countries in this region to liberalize and capitalize residential real estate investment markets (Cai, 2017; Moosa, 2020).

The US Securities and Exchange Commission in 2011 described REIT as "company that owns, typically operates income-producing real estate-related assets". REITs operate on an ideology of pooling capital from diverse sources for real estate investment capitalization, a philosophy that entails that investors can assume ownership of real estate by virtue of contributing far lesser than is required had they gone into the venture alone. This housing finance ideology is already gaining ground globally, with relatively slower accentuation in SubSaharan Africa. For instance, Nigeria has only 3 REITs listed in the Nigerian Stock Exchange, and these are Union Homes REITs, Sky Shelter Fund and UPDC REITs, otherwise referred to as N-REITs (Nigerian REITs).

In spite of the fact that N-REITs have an unbalanced focus to real estate investments that favours the residential sector, a significant bottleneck still exists. We find evidence of this bottleneck in the annual records and financial statements of N-REITs which show a generic bias towards luxury apartments in high brow areas of Abuja and Lagos, Nigeria. The focus on this investment class presents a grim anomaly when juxtaposed with the over 17 million-housing deficit statistic of which estimated $90 \%$ accounts for affordable housing (Yinglun, 2019). Still, empirical evidence (Ades, 2016; Liu et al., 2013; Robaton, 2020) illustrates the potential of REITs to effect necessary transformation of housing delivery towards a preponderance of affordable, indemnificatory or subsidized rent-geared-to-income units.

This affordable housing ambidexterity of REITs is referred to as "social purpose REITs". This class of real estate investment trusts combine economic motivations of investment with social obligation to meet a peculiar societal demand. With illustrations of the efficacy of this REIT segment in the United States and China, little has been written about its viability in Sub-Sahara Africa. Actually, the generics of this paucity of empirical literature on affordable housing REITs is one with immense global proportions (Sgro, 2017), and it is the aim of this study to examine the intricacies of affordable housing N-REITs through a Strength, Weakness, Opportunities, Threat (SWOT) analysis of its entrance into the Nigerian real estate economic and legal environment.

\subsection{Objectives of the Study}

The study is steered by the following objectives:

1. To ascertain the strengths of affordable housing REITs in Nigeria.

2. To ascertain the weaknesses of affordable housing REITs in Nigeria.

3. To ascertain the opportunities of affordable housing REITs in Nigeria.

4. To ascertain the threats to affordable housing REITs in Nigeria.

\subsection{Justification of the Study}

The study aims at appraising the strengths and weaknesses of affordable housing ambidexterity of N-REITs and highlighting opportunities for ameliorating housing deficit attenuation amidst peculiar existential threats. The study joins a plethora of empiricisms in arguing that the present composition of N-REIT portfolio is a not a path to sustainable housing market development due to its negation of the demographic realities in the country. Therefore, any transition to economic and socially sustainable housing delivery must necessarily involve a reengineering of REIT residential housing investment towards socially equitable outcomes. While we do not know the probabilities of affordable housing REITs in Nigeria at the moment, prior to the SWOT analysis, the study hypothesizes that the colossal demand for such housing in Nigeria has potentials of a turnover-driven returns characterization.

\section{Review}

The housing industry represents one of the key contributors to economic development, growth and recovery. The National Association of Home Builders in the United States posits that in the wake of the Covid-19 pandemic, the industry is at the fore of economic recovery as a result of "pent-up demand" for its units. The significance of this assertion finds credence in the study by Leamer (2015) which found the housing industry, following the economic downturn of 2008/2009, as "the single most critical part of the United States business cycle". SockYong (2010) evaluated the contribution of housing to financial sector development in Singapore and found it a significant contributor to housing wealth formation. Progressing from housing sector potential semantics to an analysis of the drivers of this potential, our review examines the potency of real estate investment trusts as a housing finance avenue.

Afolayan (2017), on the potentials of REITs as a housing finance option in Nigeria, asserts that sustainable real estate financing is in need of reengineering for sustained credit creation in the capital market. The study identified REITs as a viable investment vehicle for achieving this purpose. Adjekophori \& Adebiyi (2016) concur with the narrative with the extrapolation that "the capital market is unarguably the most robust and notable institution in any economy for mobilizing necessary funds for financing long-term projects such as 
housing delivery". However, when it comes to the utilization of this investment vehicle for the purpose of affordable housing delivery, a certain degree of complexity arises (Chan, 2016).

Extending the narrative to REIT aptitudes for affordable housing delivery, Olanrele et al. (2019) recommend a social-purpose REIT where low-income earners occupy housing developed by REITs which they also subscribe to. The issue with this recommendation is can be angled in 2 ways. First, there is no empirical evidence supporting this position. Second, in a country with significant proportion of the population living below $\$ 1$ a day, how many low-income earners would be needed to sufficiently capitalize the social-purpose REIT? It is agreeable that this number may be unsustainably high.

In a similar study, Chan (2016) posits that "in the face of growing economic inequality and housing policy failures in the US, the onus lies on the construction industry to delivery more affordable housing units than ever before". The study elaborated on this assertion with the delineation of strategy that encourages affordable housing developers to go public and raise funds in the capital market for the development of low-rent apartment units. A perusal of these studies advocating for affordable housing ambidexterity of REITs shows a unified testimonial stance that is devoid of empirical validation. In essence, since we all might agree that affordable housing REITs will be critical to attenuating affordable housing deficit in Sub-Saharan countries, where are the policy, legal, social and economic pointers towards its adoption and implementation?

Already, literature in this regard remains limited and inadequate (Sgro, 2017). Few existing studies have bothered on desk-top conceptualizations, while even fewer empirical research fail to grasp a consensual foundation on the viabilities of its adoption and application. We examine the few available to us. First, conceptualizations of social-purpose REIT see it as "vehicle for the provision of private market, mission-driven solutions for increased affordable housing development" (Ades, 2016). By implication, affordable housing REIT is a "business trust that combines the capital of several investors to provide financing for all forms of lowincome housing (Liu et al., 2013). This makes it a nimbler platform for capitalizing affordable housing delivery (Robaton, 2020).

Beyond conceptuality semantics to empirical validations of affordable housing REITs, Ades (2016) utilizes an existing affordable housing REITs, called the Housing Partnership Equity Trust (HPET), in instantiating the argument that such REITs were found to be novel instruments for the development and sustainability of safe and affordable housing across all income levels in the US through a "unique structure that allows for long-term ownership". This result may be inconclusive and antithetical to an emerging market perspective for a number of reasons. First, the US operates a frictionless mature and transparent market, as against the physiognomy of several emerging markets as Nigeria. Second, the economy of the US has greater prospects of equity capitalization of affordable housing REITs than emerging economies.

In what might be viewed as a validation of our cognitive positioning, albeit from an emerging economy as China, Huang (2010) developed a thesis with the deduction that affordable housing REITs are not viable in light of "social losses incurred by Link REIT in Hong Kong". The study conducted a comparative analysis of affordable housing REIT practice in US, Taiwan and China to reach this finding. This culminated in the conclusion by the study that the losses generated in emerging markets stem from an equity financing bias, and thus recommended for a leveraging of the capital structure of affordable housing REITs for more positive returns profile.

This result disparity and lack of consensual premise on the efficacy of affordable housing REITs provide further motivations and justifications for the study. The pertinent questions remain how to leverage the potentials of affordable housing REITs for affordable housing deficit attenuation in Nigeria, and what are the intrinsic and extrinsic challenges to this transformative process? Providing a response to these queries is essential for investors and policy makers in the Nigerian real estate industry in their quest for a more sustainable and socially equitable housing market. A growing body of empirical literature identify the legitimacy, accuracy and relevance of SWOT analysis in enquiries as we intend to embark upon (Emerole, 2018; Gurel \& Tat, 2017; Sammut-Bonici \& Galea, 2017).

The literature on this quantitative application can be categorized from two perspectives. One is the argument which suggests a "charity begins at home" approach which examines the strengths and weaknesses of the unit of analysis, prior to ascertaining the modulating effects of the external environment as measured by the opportunities and threats (Mondal, 2017; Yan, 2017; Zhifeng \& Lin, 2013). The other strand of research has its delineations on an external first approach that examines the opportunity and threatening factors to the unit of analysis prior to a survey of its internal strengths and weaknesses. This method is otherwise referred to as TOWS matrix (Adindu, 2010; Cerny et al., 2018; Dandage et al., 2019; Mugo et al., 2017).

There is indeed yet another strand of research which emphasizes a duality of approach that integrates the use of TOWS and SWOT analysis. This is premised on the argument of using SWOT to delineate the strengths, weaknesses, opportunities and threats, while TOWS matrix is utilized in ascertaining the relationship between internal and external factors (Bin-Azam, 2020; Bin-Hashim, 2020). A gap in extant literature shows evidence of a minimality of empirical applications of any or both of these strategic planning tools in determining the 
feasibility and viability of affordable housing N-REITs. To capture the directional causality of N-REITs and affordable housing delivery, country-specific proxies for measurement are essential. To further this, a review of research evidence on the strengths, weaknesses, opportunities and threats of REIT-financing of affordable housing is imperative.

a. Real Estate Investment Trusts: The Strengths

Osmadi \& Razali (2014) conducted a study to examine the performance predictors of 3 Islamic REITs (I-REITs) from 2007 to 2009. The findings of the study revealed that the growth and competitiveness potential of the REITs were predicted by a duality of financial and management strength. This study is consistent with the views of Afolayan (2017) and Cai (2017) that see the strength of REITs as an embodiment of cost-effective sound professional business and financial management. This strength is underscored by the increased performance and growth potentials of such professional input, in addition to the costlier business and financial management arrangement associated with direct real estate investment.

This position is accentuated by Onyekwelu et al. (2020) in their argument that the professional business and financial management strength of REITs "save the investor from whatever investment management deficiency they may likely possess. This adeptness has been recognized as a requisite for socioeconomically sustainable housing delivery due to investment management issues encumbering such investments (Muyingo, 2016). Hardin III et al. (2009) presented a vivid elucidation of this strength to affordable housing with a comparative analysis of the "impact of ownership and management structure on property level performance amongst traded and direct real estate". The study found that "multifamily properties owned and managed by REITs generated higher effective rents at the property level than non-REIT operated properties".

Omokhomion et al. (2018) employed systematic review method to investigate the "impact of management structures on performance of REITs regimes". The study found that benefits of REIT corporate governance are better resource organization and monitoring, rise in number of institutional investors, and efficient leverage management. Indeed, associating this strength to the sustainability of affordable housing delivery provides fascinating prospects for Sub-Saharan Africa.

Newell \& Osmadi (2009) constructed a time series analysis of risk-adjusted performance and portfolio diversification benefits of three Malaysia REITs (M-REITs) over a 3-year period that included the global economic and financial meltdown of 2008. M-REITs displayed "defensive characteristics of low-risk levels and portfolio diversification benefits. Rozman et al. (2016) assessed dynamic linkages of I-REITs in the Malaysian stock market using Granger causality test over a period of 7 years. The result highlighted the diversification potentials of I-REITs within any asset classes of shares or bonds.

Ciura (2020) examined REIT performance on the S\&P 500, MSCI US REIT index and the MSCI USA Investable Market index. The analysis showed that a significant strength of REITs is the generation of high dividend yields. This strength was accentuated by its "outperformance of other stocks listed on the S\&P 500 for decades". This prowess was explained by business regulations which seemingly favoured REIT regimes, such as the mandate to pay out at least $90 \%$ of their net income as dividend payments to shareholders. Citing the MSCI USA Investable Market index, Ciuri (2020) explained that his largesse of dividend payments is usually offset by relatively higher annual returns.

Research by Ewurum et al (2019) conducted a review on the prospects of strategic leadership in enhanced sustainable public housing delivery. The paper found a significant relationship between stimulus control and vision articulation, key indicators of corporate REIT management, and sustainable housing delivery. Jeff (2019) analyzed the prospects and constraints of investment in REITs using data from the Vanguard Real Estate Index Fund. On the prospects side, the paper outlined REIT strengths of ease of entry by prospective investors, high liquidity as a result of its stock-based capitalization as against direct real estate investments, highly diversifiable which ensures risk-adjusted returns and lower cashflow risk.

In consistency with the results of Jess (2019), Powers (2020) examined the dynamics of investing in real estate investment trusts, and found the following strengths of REITs - diversifiable, risk-adjusted returns, high dividend payments, high liquidity, professional property management, overriding of FDI restrictions on property ownership, effect of depreciation outgoings on shareholder dividend taxes, and shared ownership thus implying lesser capital commitment. Echoing the lesser capital requirement strength of REITs, Onyekwelu et al. (2020) posit that shared capitalization of REITs prevail upon the traditional huge capital outlay that characterizes direct real estate investment. REITs are able to navigate this capitalization challenge with its practice of employing capital pooled from an array of investors, while also offering each investor the prestige accompanied by ownership of land (Cai, 2017). This also entails that liabilities are shared, thereby reducing the burdens which would have led to low investor confidence. Likewise, long-term investment at $90 \%$ dividend which ensures that investor patience is sustained for the intricacies of affordable housing development is another strength of REITs in affordable housing investment.

b. Real Estate Investment Trusts: The Weaknesses Jeff (2019) examined the constraints of investment in REITs using data from the Vanguard Real Estate Index 
Fund. The paper outlined the following REIT weaknesses of taxation consequences which exempt REITs from low dividend tax rate, municipal property taxes and land use charges, and high dividend pay-out-driven rise in leverage for expansion and diversification purposes. Powers (2020) argues that REITs are also encumbered by low growth potential due to its $90 \%$ high dividend pay-outs, which leaves only $10 \%$ of investable income. This may pose negative externalities to expansion and diversification interests. Another constraint of REITs is that investors may be discouraged from investing due to the relinquishment of ownership and decision-making powers that usually accompany direct real estate investments. In agreement, Powers (2020) argues that such abdication of control is accentuated by the additional costs of professional investment management services.

c. Real Estate Investment Trusts: The Opportunities

Olugbenga et al. (2017) examined the potentials of affordable housing investment in Nigeria using Survey method. The study found that increased investments in the affordable housing sector has prospects of increased employment opportunities, with positive externalities of stimulating industries in the production of local building materials thereby reducing the cost of housing development for REITs. Likewise, Gutiérrez \& Domènech (2020) conducted a multiscale analysis of low-rent housing in Spain and found a high potential for 'new' profit generation in the housing market.

Ewurum et al. (2020) introduced a conceptual Housing Stakeholder Management Model (HSM Model) with a view to transforming institutional attitudes towards a sustainability culture of housing delivery that meets safety and affordability needs of the target population. The study used Exploratory research design amongst a population of 385 real estate professionals and policy makers. Data was analyzed quantitatively with OneSample Kolmogorov-Smirnov Test and Spearman Correlation, while qualitative data analysis employed Scissorsort Technique and TEXTPACK. Upon model validation with a SWOT Analysis, the findings advance the HSM Model's effectiveness in identifying stakeholder interests and establishing a sustainability framework of engagement for organizations with affordable housing investment concerns, such as affordable housing REITs.

In Ekpo's (2019) affordable housing deficit analysis for Nigeria, the following findings were observed with implications for opportunities of investing in the sector. First, the study found asymmetric movements of growth in population and growth in demand for affordable housing in the country. The study also found that affordable housing investors can exploit financing incentives provided by government for such investments. The study also found increased prospects of investor attraction, including foreign direct investment, due to the potentials of growth within the sector. It also echoed the contributions of Olugbenga et al. (2017) on the prospects of increased employment generation.

Glover et al. (2017) explored novel ideas on the potentials of affordable housing investment in an environment with little or no government subsidies. The study employed interviews with housing stakeholders in Atlanta, Jacksonville, and Nashville, United States. The study found cost-saving opportunities as reduced building and development permit barriers. The study also echoed Ewurum's (2020) stakeholder approach with the identification of opportunities for less challenging affordable housing investment, through a unified constituency of stakeholders advocating more lower income-based housing.

Yue (2006) examined the housing industry in Asia and found the following opportunities for Asian REITs. First, the relatively small capitalization of Asian REITs within the less mature Asian housing market, imply that there is still significant room for growth. The prospect of investing in affordable real estate markets occasioned a blue ocean strategy for Asian REITs with a view to value creation and appreciation.

d. Real Estate Investment Trusts: The Threats

Zou's (2017) study emphasized the place of legislation and policies on REIT performance in affordable housing markets. The study found that affordable housing REITs failed in China as a result of regulatory requirements which supported the use of debt-financing over equity. Obi-Aso et al. (2020) investigated the relationship between ownership risk and sustainability planning of organizations in Nigeria. The study identified land policy, land titling irregularities, inconsequential compensation procedures, and mortgage loan delays. The relationship between these ownership risk variables and sustainability planning were analyzed using Spearman's Rank Order Correlation, and the findings show that a significant negative effect existed between ownership risk and sustainability planning for FDI real estate organizations in Nigeria.

We revisit Ekpo (2019) and Yue (2006) to capture their findings on the threats to affordable housing REITs. First, Ekpo (2019) resonated the work of Obi-Aso et al. (2020) on the perception of land policy as threat. The study observed a high level of insecurity in the Nigerian land tenure system, inadequacy of housing information system, high interest rates and inflation - which it adjudged to have dissuaded real estate investment in the country. Yue (2006) on the other hand, outlined immature housing markets and low transparency, and imperfect legislative system as threats to affordable housing REITs in developing countries.

Research by Adzinku (2016) had the aim of identifying prospective interventions for improving affordable housing delivery in Ghana. The study employed structured questionnaire and interview on a sample frame of 160 respondents. Upon employing relative importance index and descriptive analysis, the study found that threats to affordable housing investment were ineffective housing policies and weak housing institutions. 
The study follows the findings of these studies in building a SWOT Analysis research instrument for our investigation with a view to extricating the peculiar realities for N-REITs in a Nigerian setting.

\section{Methodology}

A quantitative approach was adopted to examine the strengths, weaknesses, opportunities and threats to affordable housing ambidexterity of Nigerian real estate investment trusts. This entailed a survey of housing stakeholders consisting fund investors, managers, real estate developers [from real estate developers association of Nigeria (REDAN)], staff of State housing development corporation, ministry of housing, National Housing Fund, and Federal Housing Authority in Lagos, Nigeria. The study adopted a self-administered e-questionnaire, developed with Google forms. Sample size was determined using Freund and Williams formula for infinite population, and this is expressed thus:

$$
\frac{\mathrm{Z}^{2} \mathrm{pq}}{\mathrm{e}^{2}}
$$

Where:

$\begin{array}{lll}\mathrm{n} & = & \text { sample size } \\ \mathrm{p} & = & \text { percentage of positive outcome }(0.6) \\ \mathrm{q} & = & \text { percentage of negative outcome }(0.4) \\ \mathrm{e} & = & \text { margin of error }(5 \%) \\ \mathrm{Z} & = & \text { level of confidence }(1.96) \text { indicating a } 95 \% \text { rate }\end{array}$

Therefore:

$\begin{array}{rlll}\mathrm{n} & =\frac{(1.96)^{2}(0.6)(0.4)}{0.05^{2}} & = & \frac{0.921984}{0.0025} \\ \mathrm{n} & = & 368.7936\end{array}$

Sample size $(\mathrm{n}) \quad=\quad$ approximately 369.

The sampling technique employed by the study was Snowballing technique, while content validity was used to screen the questionnaire incorporation with inputs made by 6 experts from the fields of Economics, Estate Management and Management disciplines. The test of reliability was determined using the test-retest technique, where 30 copies of the questionnaire were administered twice to the sample frame clusters at a 2-week interval. Cronbach's Alpha was then used in the consistency analysis, as follows:

Table 1: Case Processing Summary

Case Processing Summary

\begin{tabular}{|ll|l|l|}
\hline & $\mathrm{N}$ & $\%$ \\
\hline Cases & Valid & 27 & 90.0 \\
& Excluded $^{\mathrm{a}}$ & 3 & 10.0 \\
& Total & 30 & 100.0 \\
\hline
\end{tabular}

a. Listwise deletion based on all variables in the procedure.

Table 2: Reliability Statistics

Reliability Statistics

\begin{tabular}{|l|l|l|}
\hline Cronbach's Alpha & Cronbach's Alpha Based on Standardized Items & N of Items \\
\hline .873 & .854 & 31 \\
\hline
\end{tabular}

The reliability co-efficient index was .873 , and with this result, the questionnaire was deemed reliable in terms of level of consistency. Data obtained from primary sources were subjected to descriptive analysis and subsequently ranked where ' 1 ' indicates most significant attribute.

\section{Empirical Results}

The questionnaire return rate was $79 \%$ indicating a successful return of 292 copies. Tables 1 to 8 indicate the descriptive analysis results of the survey and ranking of outcomes with respect to the strengths, weaknesses, opportunities and threats to affordable housing ambidexterity of N-REITs.

a. Strength of N-REIT ambidexterity to Affordable Housing Delivery

Tables 1 to 2 indicate the generic, significant and least dominant strengths of affordable housing 
Table 1: Strengths of Affordable Housing REITs

Descriptive Statistics

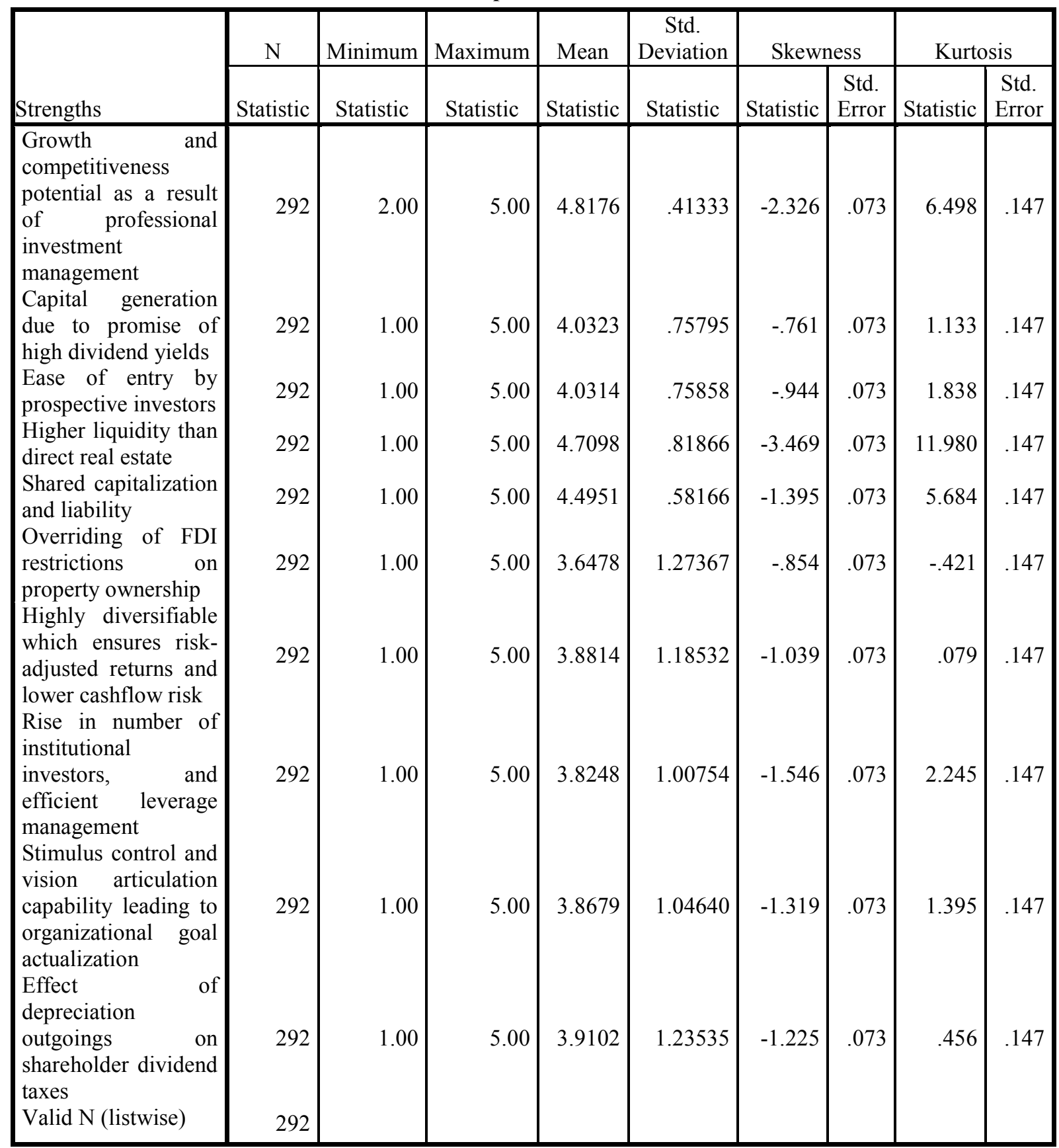

Table 1 is the descriptive statistics of the strengths of affordable housing REIT in Nigeria, as obtained from the Likert Scale-structured research instrument. In Table 2, the results are further ranked in accordance with the mean with a view to extricating the dominant strength of N-REIT ambidexterity to affordable housing delivery in Nigeria. 
Table 2: Ranking of the Strengths of Affordable Housing N-REITs

\begin{tabular}{|l|l|l|}
\hline & Mean & Rank \\
\cline { 2 - 3 } Strengths & Statistic & 1 to 10 \\
\hline $\begin{array}{l}\text { Growth and competitiveness potential as a result of professional investment } \\
\text { management }\end{array}$ & 4.8176 & 1 \\
Capital generation due to promise of high dividend yields & 4.0323 & 4 \\
Ease of entry by prospective investors & 4.0314 & 5 \\
Higher liquidity than direct real estate & 4.7098 & 2 \\
Shared capitalization and liability & 4.4951 & 3 \\
Overriding of FDI restrictions on property ownership & 3.6478 & 10 \\
Highly diversifiable which ensures risk-adjusted returns and lower cashflow risk & 3.8814 & 7 \\
Rise in number of institutional investors, and efficient leverage management & 3.8248 & 9 \\
Stimulus control and vision articulation capability leading to organizational goal & 3.8679 & 8 \\
actualization & 3.9102 & 6 \\
Effect of depreciation outgoings on shareholder dividend taxes & &
\end{tabular}

Table 2 is the ranking of the strengths of N-REIT ambidexterity to affordable housing investment, where 1 is ranked the dominant strength, while 10 indicates the least dominant strength. From the analysis, growth and competitiveness potential due to professional investment management competency was the most dominant strength of N-REIT ambidexterity to affordable housing investment in Nigeria. On the other hand, overriding of restrictions to FDI ownership of landed property was the least significant strength of N-REIT ambidexterity to affordable housing investment in Nigeria.

b. Weaknesses of N-REIT Ambidexterity to Affordable Housing Delivery

Tables 2 to 4 indicate the generic, significant and least dominant weaknesses of affordable housing ambidexterity of N-REITs. 
Table 3: Weaknesses of Affordable Housing REITs

Descriptive Statistics

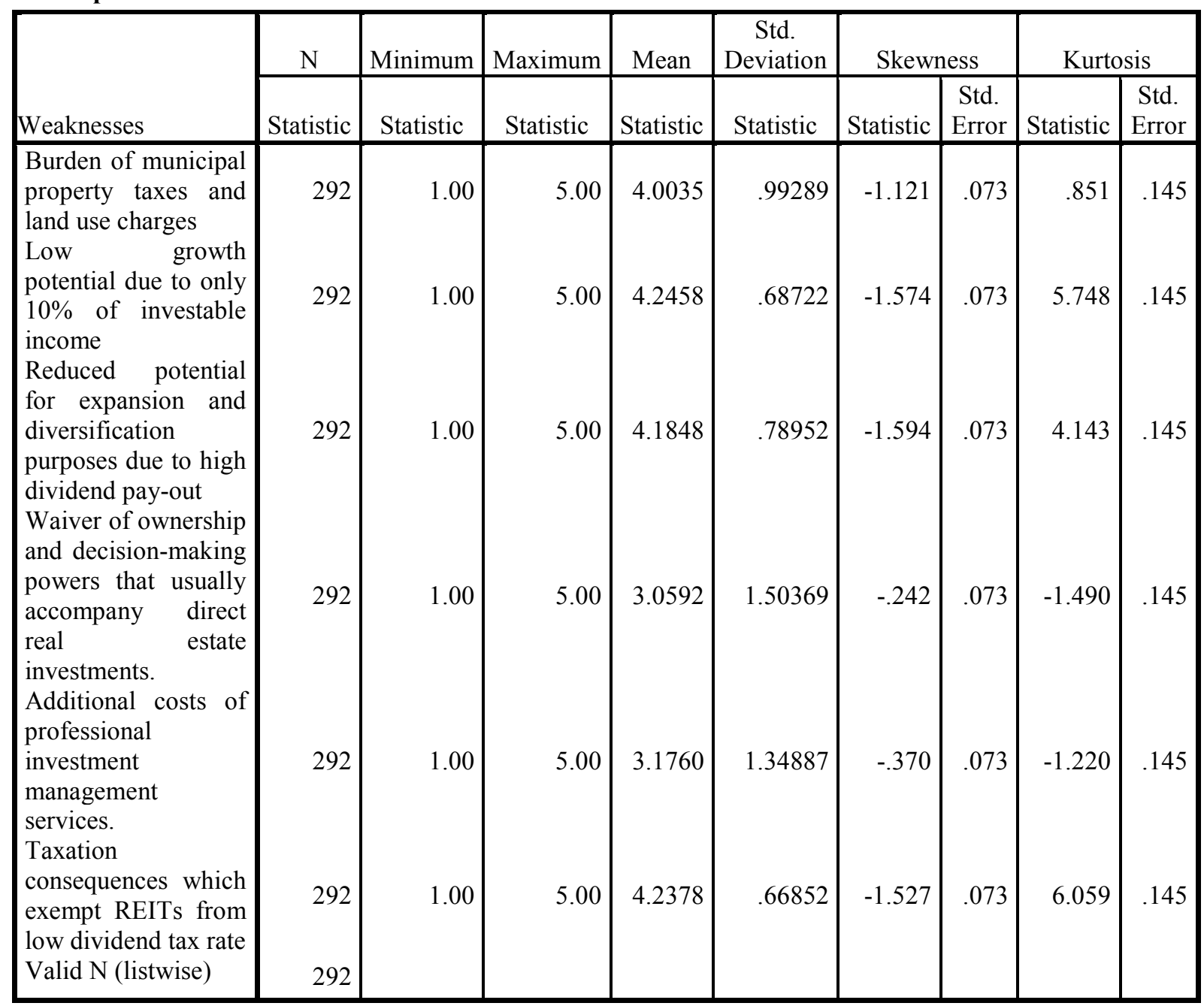

Table 3 shows the descriptive statistics of the weaknesses of affordable housing REIT in Nigeria, as obtained from the Likert Scale-structured research instrument. In Table 4, the results are further ranked in accordance with the mean with a view to extricating the most significant weakness of N-REIT ambidexterity to affordable housing delivery in Nigeria.

Table 4: Ranking of the Weaknesses of Affordable Housing N-REITs

\begin{tabular}{|l|r|c|}
\hline & Mean & Rank \\
\cline { 2 - 3 } Weaknesses & Statistic & 1 to 6 \\
\hline Burden of municipal property taxes and land use charges & 4.0035 & 4 \\
Low growth potential due to only 10\% of investable income & 4.2458 & 1 \\
Reduced potential for expansion and diversification purposes due to high dividend & 4.1848 & 3 \\
$\quad$ pay-out & 3.0592 & 6 \\
Waiver of ownership and decision-making powers that usually accompany direct \\
$\quad$ real estate investments. & 3.1760 & 5 \\
Additional costs of professional investment management services. & 4.2378 & 2 \\
Taxation consequences which exempt REITs from low dividend tax rate & \\
Valid N (listwise) & \\
\hline
\end{tabular}

Table 4 is the ranking of the weaknesses of N-REIT ambidexterity to affordable housing investment, where 1 is ranked the most significant weakness, and 6 indicates the least significant weakness. From the analysis, low growth potential due to only $10 \%$ of investable income was the most significant weakness of N-REIT ambidexterity to affordable housing investment in Nigeria. Conversely, ownership and decision-making 
abdication for professional investment management was the least significant weakness of N-REIT ambidexterity to affordable housing investment in Nigeria.

c. Opportunities of N-REIT ambidexterity to Affordable Housing Delivery

Tables 5 to 6 specify the generic, significant and least dominant opportunities of affordable housing ambidexterity of N-REITs.

Table 5: Opportunities of Affordable Housing REITs

Descriptive Statistics

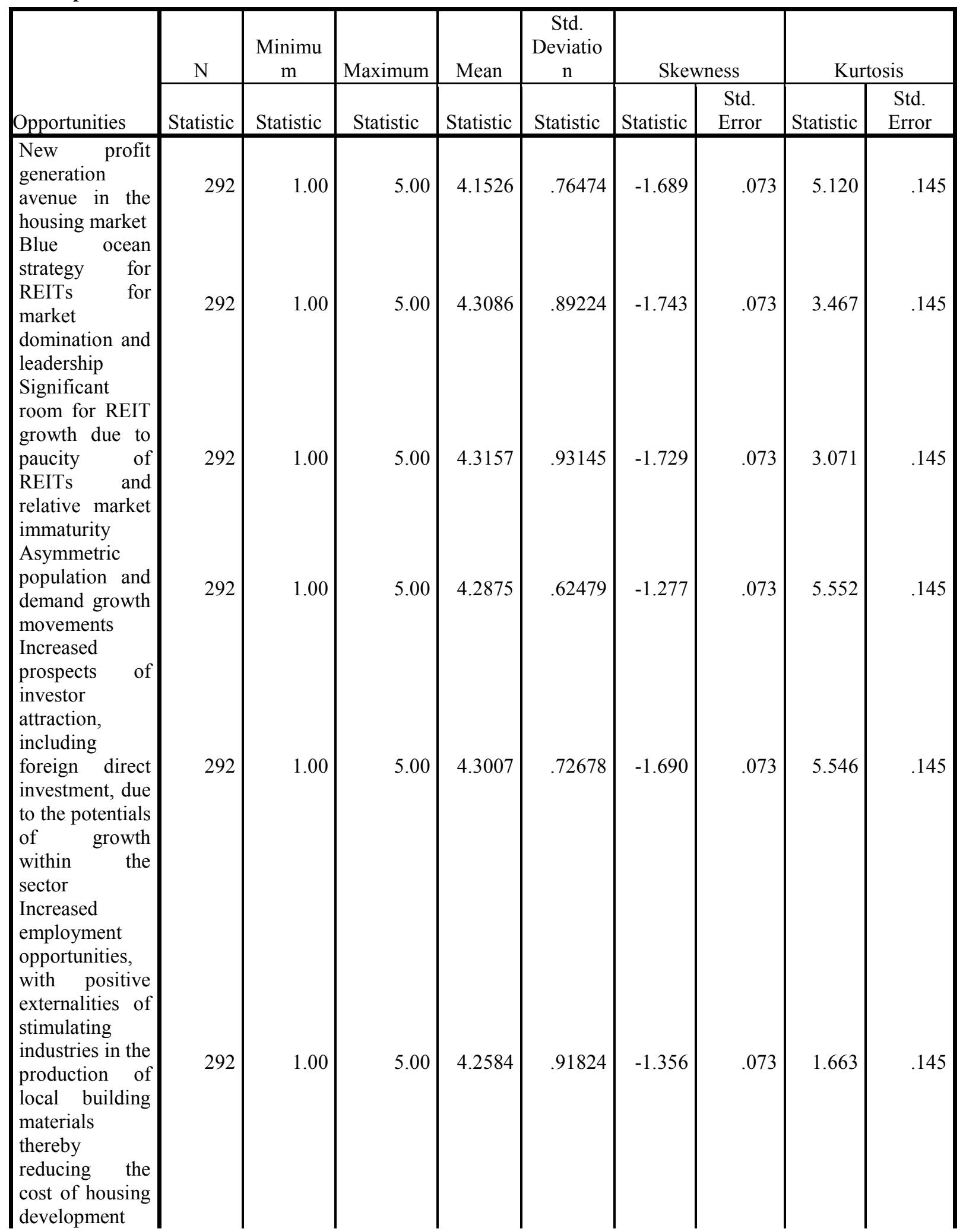




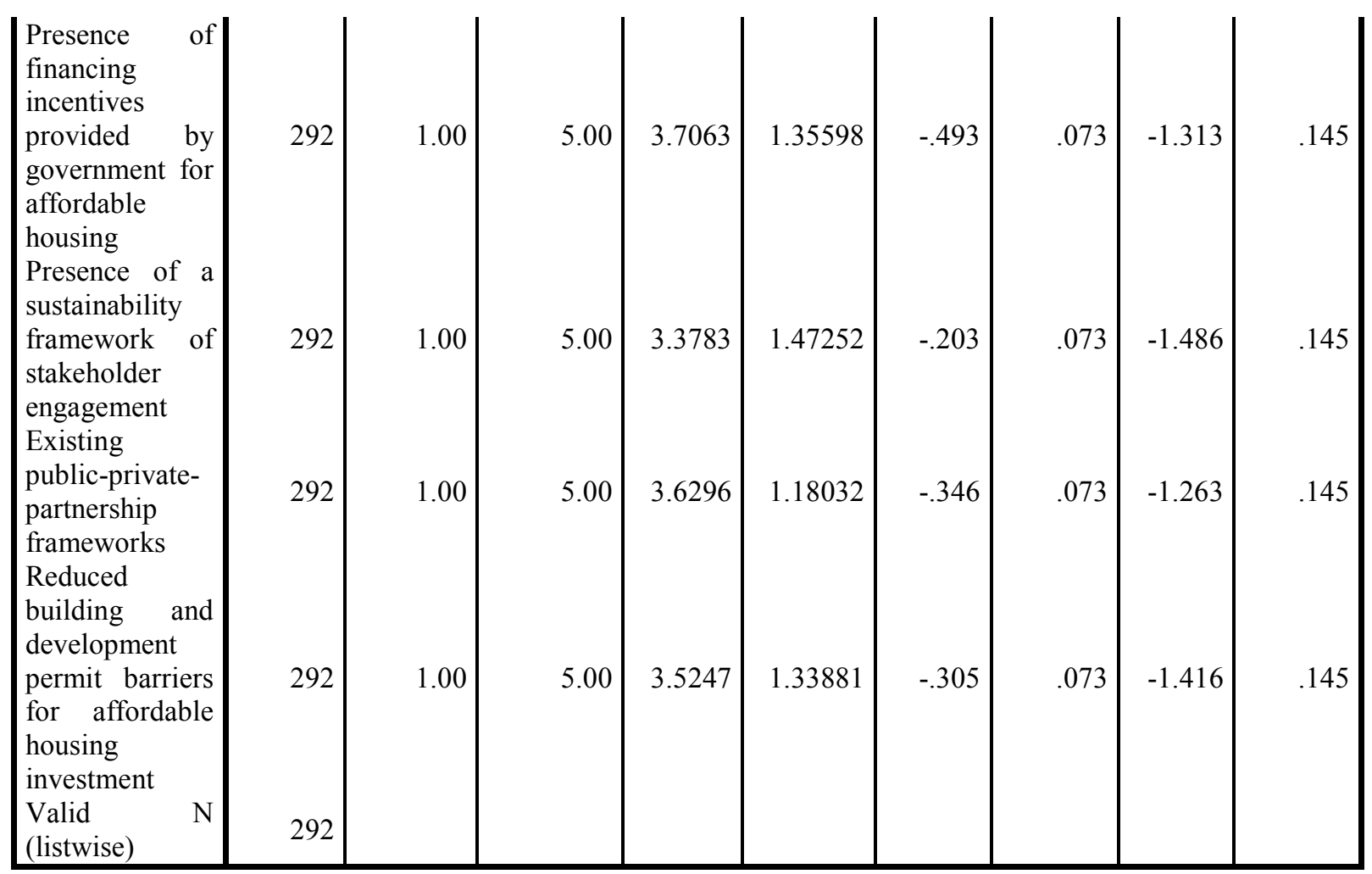

Table 5 shows the descriptive statistics of the opportunities of affordable housing REIT in Nigeria, as obtained from the Likert Scale-structured research instrument. Table 6 shows the ranking of the mean statistics with a view to extricating the most significant opportunity of N-REIT ambidexterity to affordable housing delivery in Nigeria.

Table 6: Ranking of the Opportunities of Affordable Housing N-REITs

\begin{tabular}{|c|c|c|}
\hline \multirow{2}{*}{ Opportunities } & Mean & Rank \\
\hline & Statistic & 1 to 10 \\
\hline New profit generation avenue in the housing market & 4.1526 & 6 \\
\hline Blue ocean strategy for REITs for market domination and leadership & 4.3086 & 2 \\
\hline $\begin{array}{l}\text { Significant room for REIT growth and increase in market share due to paucity of } \\
\text { REITs and relative market immaturity }\end{array}$ & 4.3157 & 1 \\
\hline Asymmetric population and demand growth movements & 4.2875 & 4 \\
\hline $\begin{array}{l}\text { Increased prospects of investor attraction, including foreign direct investment, due } \\
\text { to the potentials of growth within the sector }\end{array}$ & 4.3007 & 3 \\
\hline $\begin{array}{l}\text { Increased employment opportunities, with positive externalities of stimulating } \\
\text { industries in the production of local building materials thereby reducing the } \\
\text { cost of housing development }\end{array}$ & 4.2584 & 5 \\
\hline Existing financing incentives provided by government for affordable housing & B.7063 & 7 \\
\hline Presence of a sustainability framework of stakeholder engagement & B.3783 & 10 \\
\hline Existing public-private-partnership frameworks & B.6296 & 8 \\
\hline $\begin{array}{l}\text { Reduced building and development permit barriers for affordable housing } \\
\text { investment } \\
\text { Valid N (listwise) }\end{array}$ & 3.5247 & 9 \\
\hline
\end{tabular}

Table 6 is the ranking of the opportunities of N-REIT ambidexterity to affordable housing investment, where 1 is ranked the most significant opportunity, and 10 indicates the least significant opportunity. From the analysis, significant room for REIT growth and rise in market share due to paucity of REITs and relative market immaturity was the most significant opportunity of N-REIT ambidexterity to affordable housing investment in Nigeria. Conversely, presence of a sustainability framework of stakeholder engagement was the least significant opportunity of N-REIT ambidexterity to affordable housing investment in Nigeria.

d. Threats to N-REIT ambidexterity to Affordable Housing Delivery 
Generic, significant and least dominant threats to affordable housing ambidexterity of N-REITs are shown in Tables 7 to 8 .

Table 7: Threats to Affordable Housing REITs

\begin{tabular}{|c|c|c|c|c|c|c|c|c|c|}
\hline \multirow[b]{2}{*}{ Threats } & \multirow{2}{*}{$\frac{\mathrm{N}}{\mathrm{Statistic}}$} & \multirow{2}{*}{$\begin{array}{l}\text { Minimum } \\
\text { Statistic }\end{array}$} & \multirow{2}{*}{\begin{tabular}{c|} 
Maximum \\
Statistic \\
\end{tabular}} & \multirow{2}{*}{$\begin{array}{l}\text { Mean } \\
\text { Statistic }\end{array}$} & \multirow{2}{*}{$\begin{array}{c}\text { Std. } \\
\text { Deviation } \\
\text { Statistic } \\
\end{array}$} & \multicolumn{2}{|c|}{ Skewness } & \multicolumn{2}{|c|}{ Kurtosis } \\
\hline & & & & & & Statistic & $\begin{array}{l}\text { Std. } \\
\text { Error }\end{array}$ & Statistic & $\begin{array}{l}\text { Std. } \\
\text { Error }\end{array}$ \\
\hline $\begin{array}{l}\text { Land ownership risk } \\
\text { such as land policy, } \\
\text { titling irregularities, } \\
\text { inconsequential } \\
\text { compensation } \\
\text { procedures }\end{array}$ & 292 & 1.00 & 5.00 & 4.0492 & .99615 & -1.012 & .072 & .508 & .145 \\
\hline $\begin{array}{l}\text { Stringent mortgage } \\
\text { framework such as } \\
\text { cumbersome } \\
\text { processes and high } \\
\text { interest rates }\end{array}$ & 292 & 1.00 & 5.00 & 4.2151 & .72992 & -1.579 & .072 & 5.085 & .145 \\
\hline $\begin{array}{l}\text { Inadequacy of } \\
\text { housing information } \\
\text { system }\end{array}$ & 292 & 1.00 & 5.00 & 4.1993 & .81601 & -1.431 & .072 & 3.074 & .145 \\
\hline $\begin{array}{l}\text { Low market } \\
\text { transparency posing } \\
\text { systematic risk for } \\
\text { effective } \\
\text { sustainability } \\
\text { planning }\end{array}$ & 292 & 1.00 & 5.00 & 4.6102 & .60383 & -1.964 & .072 & 5.879 & .145 \\
\hline $\begin{array}{l}\text { High level of } \\
\text { insecurity in land } \\
\text { tenure system }\end{array}$ & 292 & 1.00 & 5.00 & 3.1089 & 1.34298 & .274 & .072 & -1.556 & .145 \\
\hline $\begin{array}{l}\text { Stringent regulatory } \\
\text { requirements }\end{array}$ & 292 & 1.00 & 5.00 & 2.8534 & 1.63779 & .133 & .072 & -1.679 & .145 \\
\hline $\begin{array}{l}\text { Imperfect legislative } \\
\text { system }\end{array}$ & 292 & 1.00 & 5.00 & 4.3977 & .78700 & -1.903 & .072 & 4.849 & .145 \\
\hline $\begin{array}{ll}\text { Weak } & \text { housing } \\
\text { institutions } & \end{array}$ & 292 & 1.00 & 5.00 & 2.1045 & 1.18891 & 1.070 & .072 & .070 & .145 \\
\hline $\begin{array}{l}\text { Ineffective housing } \\
\text { policies } \\
\text { Valid N (listwise) }\end{array}$ & $\begin{array}{l}292 \\
292\end{array}$ & 1.00 & 5.00 & 3.4486 & 1.60506 & -.150 & .072 & -1.807 & .145 \\
\hline
\end{tabular}

Table 7 shows the descriptive statistics of the threats to affordable housing REIT in Nigeria, as obtained from the Likert Scale-structured research instrument. Table 8 is the ranking of the mean statistics with a view to extricating the most significant threat to N-REIT ambidexterity towards affordable housing delivery in Nigeria. 
Table 8: Ranking of the Threats to Affordable Housing N-REITs

\begin{tabular}{|l|c|c|}
\hline & Mean & Rank \\
\cline { 2 - 3 } Threats & Statistic & 1 to 9 \\
\hline $\begin{array}{l}\text { Land ownership risk such as land policy, titling irregularities, inconsequential } \\
\text { compensation procedures }\end{array}$ & 5.0492 \\
$\begin{array}{l}\text { Stringent mortgage framework such as cumbersome processes and high interest } \\
\text { rates }\end{array}$ & 4.2151 & 3 \\
Inadequacy of housing information system & 4.1993 & 4 \\
Low market transparency posing systematic risk for effective sustainability & 4.6102 & 1 \\
$\quad \begin{array}{l}\text { planning } \\
\text { High level of insecurity in land tenure system }\end{array}$ & 3.1089 \\
Stringent regulatory requirements & 2.8534 & 8 \\
Imperfect legislative system & 4.3977 & 2 \\
Weak housing institutions & 2.1045 & 9 \\
Ineffective housing policies & 3.4486 & 6 \\
Valid N (listwise) & & \\
\hline
\end{tabular}

Table 8 shows the ranking of the threats to N-REIT ambidexterity to affordable housing investment, where 1 is ranked the most significant threat, and 9 is the least significant threat. From the analysis, systematic risk from low market transparency and maturity affecting sustainability planning was the most significant threat to NREIT ambidexterity towards affordable housing investment in Nigeria. Conversely, perceived weakness of housing institutions was the least significant threat to N-REIT ambidexterity towards affordable housing investment in Nigeria.

\section{Summary of Findings}

From the analysis and results on the strengths, weaknesses, opportunities and threats to affordable housing ambidexterity of N-REITs, the following findings were made:

i. Professional investment management competency was the most dominant strength of N-REIT ambidexterity to affordable housing investment in Nigeria.

ii. Low growth and expansion potential due to only $10 \%$ of investable income was the most significant weakness of N-REIT ambidexterity to affordable housing investment in Nigeria.

iii. Significant room for rise in market share due to paucity of REITs and relative market immaturity was the most significant opportunity of N-REIT ambidexterity to affordable housing investment in Nigeria.

iv. The effect of systematic risk from low market transparency and maturity on sustainability planning was the most significant threat to N-REIT ambidexterity towards affordable housing investment in Nigeria.

\section{Conclusion}

Since inception in 2008, N-REITs have been characterized by relatively convincing market capitalization and performance. Using SWOT analysis, the affordable housing ambidexterity of N-REITs was examined. From the findings of the SWOT analysis, the study concluded that the professional investment management quality of REITs, in comparison with non-listed direct real estate companies would envisage a robust and sustainable contribution to increase in affordable housing stock in the country.

\section{Recommendations}

In light of the findings, the study recommended as follows:

I. Management of N-REITs should leverage on their professional investment management strengths to explore blue ocean strategies for an ambidextrous attitude that enhances the growth and sustainability of affordable housing units. However, they should be mindful of the effect of their idiosyncratic risks on such decisions.

II. Capital structure of N-REITs should be more debt-driven to ensure an augmentation of the $10 \%$ investable income, so as to allow room for further diversification expansion and growth. The issue to be contemplated here though is where the REIT insists on an equity-driven capital structure, to what extent are shareholders willing to commit to less than $90 \%$ dividend pay-out policy? Also, what is the regulatory position on such reduction? This provides the motivation for further studies. 
III. The number of established REITs in the Nigerian stock market is 3 and this comprises Sky Shelter Fund, Union Homes, and UPDC REITs. This relatively low number implies that any REIT with affordable housing ambidexterity has the possibilities of increasing its market share and prospective new profit generation prior to possible market diffusion and saturation.

IV. Management of N-REITs should employ risk analysis, management and mitigation strategies to limit the effect of volatilities from macroeconomic risks.

Disclosure of Conflict of Interest

The authors disclose no conflict of interest in this paper.

\section{References}

Ades, D. (2016). Preserving existing affordability through a social purpose REIT. Journal of Case Study Research, 1(1).

Adindu, C. (2010). Application of threats, opportunities, weaknesses and strengths (TOWS) matrix strategic planning model in manufacturing firms in Nigeria. Thesis, Department of Management, University of Nigeria.

Adjekophori, B., Adebiyi, S. (2016). Effectiveness of capital market derivatives in housing delivery of Nigeria emerging market. Economic Sciences Centre for Economic Studies and Research, University of Bacau. DOI: http://dx.doi.org/10.29358/sceco.v0i23.339

Adzinku, A. (2016). Exploring potential interventions for improving affordable housing for low-income earners in Ghana. Building Technology, College of Art and Built Environment, Kwame Nkrumah University of Sceince and Technology, Ghana

Afolayan, A. (2017). Exploring Real Estate Investment Trust (REIT) as a housing finance option in Nigeria. Ethiopian Journal of Environmental Studies and Management 10(1)

Aliu, I., Towry-Coker, L. \& Odumosu, T. (2018). Housing policy debacle in Sub-Saharan Africa: An appraisal of three housing programs in Lagos Nigeria, African. Geographical Review, 37(3), 241-256, DOI: $10.1080 / 19376812.2017 .1284005$

Aso, N.E., Aguome, N.M. \& Nebo, L.I. (2020). Host country ownership risk and FDI sustainability planning: Evidence from commercial real estate portfolios. International Journal of Business and Management Invention, 9(6:I), 10-17.

Bin Azam, A. (2020). SWOT and TOWS matrix analysis towards life raft service station: A case study on Dyzara SDN BHD. University of Kuala Lumpur.

Bin Hashim, M. (2020). SWOT and TOWS matrix analysis: A Case study on BME Logistics SDN BHD. University of Kuala Lumpur.

Cai, Y. (2017). The use of REITs as an alternative source to finance senior housing development in China. Master of Science, Real Estate Development, Center for Real Estate.

Černý, I., Vaněk, M. \& Hubáček, J. (2018). New approach to evaluate the TOWS matrix and its application in a mining company. Journal of the Southern African Institute of Mining and Metallurgy, 118(12). http://dx.doi.org/10.17159/2411-9717/2018/v118n12a8

Chan, X. (2016). Why affordable housing developers should go public : REITs as an alternative source of capital for housing development. S.M. in Real Estate Development, Massachusetts Institute of Technology, Program in Real Estate Development in conjunction with the Center for Real Estate.

Ciura, B. (2020). List of all REITs. https://www.suredividend.com/reit-list/\#why. Assessed on October, 2020.

Cote, A. \& Tam, H. (2013). Affordable housing in Ontario: Mobilizing private capital in an era of public constraint. IMFG Perspectives, 3

Dandage, R.V., Mantha, S.S. and Rane, S.B. (2019). Strategy development using TOWS matrix for international project risk management based on prioritization of risk categories. International Journal of Managing Projects in Business, 12(4), pp. 1003-1029. https://doi.org/10.1108/IJMPB-07-2018-0128.

Ding, D. \& Lian, W. (2018). The Long-Run Trend of Residential Investment in China. IMF Working Paper Asia and Pacific Department.

Ekpo, A. (2019). Housing deficit in Nigeria: Issues, challenges and prospects. Economic and Financial Review, $57(4)$.

Emerole, G. (2018). Risks and opportunities in emerging markets international real estate investment: A comparative analysis of Nigeria and South Africa. Journal of the Nigerian Institution of Estate Surveyors and Valuers, 41(1), 2018, $71-78$

Ewurum, N.I., Aniagolu, C.O. \& Igwe, C.P. (2020). Sustainable public housing delivery in Nigeria: A conceptual Stakeholder Management Model. Journal of Economics and Sustainable Development, 11(10), 36

Ewurum, N.I., Egolum, C.C. \& Ogbuefi, J.U. (2019). Strategic leadership as chiropractor for unsustainable 
public housing delivery in Nigeria: Research agenda. International Journal of Business and Management Invention, 8(3:V) 62-71.

Gillespie, T. (2018). Collective self-help, financial inclusion, and the commons: Searching for solutions to Accra's housing crisis. Housing Policy Debate, 28(1), 64-78, DOI: 10.1080/10511482.2017.1324892

Glover, R., Carpenter, A. \& Duckworth, R. (2017). Developing inclusive communities: Challenges and opportunities for mixed-income housing. Community \& Economic Development Discussion Paper No. 1-17

Gürel, E. \& Tat, M. (2017). SWOT analysis: A theoretical review. The Journal of International Social Research, $10(51), 2017$.

Gutiérrez, A. \& Domènech, A. (2020). Understanding the spatiality of short-term rentals in Spain: Airbnb and the intensification of the commodification of housing. Geografisk Tidsskrift-Danish Journal of Geography, 120:2, 98-113, DOI: 10.1080/00167223.2020.1769492

Hardin III, W., Hill, M. and Hopper, J. (2009). Ownership structure, property performance, multifamily properties, and REITs. Journal of Real Estate Research, 31(3), 285-306.

Huang, Y, (2010). An investigation into the use of REITs to finance affordable housing in Mainland China. Urban Studies and Planning, Massachusetts Institute of Technology.

Jeff, D. (2019). Investing in REITs: The issues. Assessed on October $2020 \mathrm{https}: / / \mathrm{www} . d e b t f r e e d r . c o m / p r o s-$ and-cons-of-reits/

Kieti, R.M. \& K'Akumu, O.A. (2018). Critical factors affecting affordability of mortgage housing in Kenya. Journal of Housing and the Built Environment, 33, 111-131. https://doi.org/10.1007/s10901-017-9547-4

Leamer, E. (2015). Housing really is the business cycle: What survives the lessons of 2008-09? Journal of Money, Credit and Banking, 47(1): 43-50. https://doi.org/10.1111/jmcb.12189

Liu, X., Wu, D., Li, X. \& Dong, J. (2013). Financing of low-rent housing REITs in China. Journal of Systems Science and Information, 1(1).

Mondal, S. (2017). SWOT analysis and strategies to develop sustainable tourism in Bangladesh. UTMS Journal of Economics, 8(2), 159-167.

Moosa, I. (2020). Stock market contagion in the early stages of the global financial crisis: The experience of the GCC Countries. International Journal of Banking and Finance, 1(7), 19-34

Mugo, M., Kamau, F., Mukabi,M. \& Kemunto, C. (2017). Using tows matrix as a strategic decision-making tool in managing KWS product portfolio. African Multidisciplinary Journal of Research, 2(1).

Muyingo, H. (2016). Challenges in property management within the Swedish cooperative housing sector. Stockholm. Retrieved from http://urn.kb.se/resolve?urn=urn:nbn:se:kth:diva-181911 in January, 2020.

Newell, G. \& Osmadi, A. (2009). The development and preliminary performance analysis of Islamic REITs in Malaysia. Journal of Property Research, 26:4, 329-347, DOI: 10.1080/09599916.2009.485417

Olanrele, O., Adegunle, T., Jolaoso, B. \& Bin Said, R. (2019). The Case of Affordable Housing: A global perspective on financing and institutional ownership. The Bartlett School of Construction and Project Management International Conference Bartlett Real Estate Institute., September, 12

Olugbenga, T., Yusoff, N., Abd Aziz, N., Baba, A. (2017). Unleashing the potentials of housing sector in Nigeria as perceived by users. International Journal of Built Environment and Sustainability, 4(3)

Omokhomion, I. \& Egbu, C. (2018). Real Estate Investment Trusts (REITs): Management structure and performance. RELAND: International Journal of Real Estate \& Land Planning, 1.

Onyekwelu, E., Anih, P. \& Nwaibe, C. (2020). Dilating low-income housing financing: Lessons for emerging market REITs. European Journal of Business and Management, 12(18), 47

Osmadi, A. \& Razali, M. (2006). Assessing the financial and management strength of Islamic real estate investment trusts (I-REITS) during the global financial crisis. Pacific RIM Real Estate Society Conference, 22-26 january, Auckland on the Development of REITs in Asia, 48-70.

Powers, S. (2020). Dynamics of REIT investment. https://www.moneycrashers.com/real-estate-investment-trustinvesting-reits/. Assessed on October 2020

Robaton, A. (2020). REITs take on affordable housing problem. Real Assets Adviser, 7(3)

Rozman, A., Razali, M., Azmi, N. \& Ali, H. (2016). The dynamic of linkages of Islamic REITs in mixed-asset portfolios in Malaysia. Pacific Rim Property Research Journal, 22:3, 245-265, DOI: 10.1080/14445921.2016.1235758

Sammut-Bonnici, T. and Galea, D. (2017). SWOT analysis. Retrieved from https://www.researchgate.net/publication/272353031 on October, 2020.

Sgro, A. (2017). Creating value: Using social purpose real estate investment trusts to support affordable housing. Master of Planning in Urban Development, Ryerson University, Ontario, Canada

Sock-Yong, P. (2010). Housing policy, wealth formation and the Singapore Economy. Housing Studies, 16:4, 443-459, DOI: 10.1080/02673030120066545

Suhaida, M., Tawil, N., Hamzah, N., Che-Ani, A., Basri, H. \& Yuzainee, M. (2011). Housing affordability: A conceptual overview for house price index. Paper presented at the 2nd International Building Control 
Conference 2011, Procedia Engineering 20, 346 - 353

World Bank Group (2015). Stocktaking of the housing sector in Sub-Saharan Africa. Washington: The International Bank for Reconstruction and Development/The World Bank. Assessed October, 2020. https://www.worldbank.org/content/dam/Worldbank/document/Africa/Report/stocktaking-of-the-housingsector-in-sub-saharan-africa-summary-report.pdf

Yan, S., A. (2017). SWOT Analysis of Chinese construction firms at the international market. Advances in Economics, Business and Management Research, 31, 2017.

Yi,Z., Liu, G., Lang, W., Shrestha, A. \& Martek, I. (2017). Strategic approaches to sustainable urban renewal in developing countries: A case study of Shenzhen, China. Sustainability, 9, 1460; doi:10.3390/su9081460

Yinglun, S. (2019). Africa needs 1.4 Trillion USD to plug affordable housing deficit. Assessed on October, 2020. http://www.xinhuanet.com/english/africa/2019-

08/13/c 138306312.htm\#: :text=The\%20firm's\%20research\%20showed\%20that,in\%20the\%20affordable $\% 20$ housing\%20bracket.

Zhifeng, G. and Lin, Z. (2013). The SWOT analysis to the development of golf tourism in Yunnan Province. International Conference on Education Technology and Management Science (ICETMS), 2013.

Zou, L. (2017). REITs and securitization as innovative modes to finance affordable housing in China. Thesis: M.C.P., Massachusetts Institute of Technology, Department of Urban Studies and Planning. 